\title{
Unlawful Acts in Maritime Transport \& Civil Aviation
}

\section{Nezakonite radnje u pomorskom prijevozu i civilnom zrakoplovstvu}

\author{
Andrea Galieriková \\ University of Ziilna \\ Department of Water Transport \\ Slovakia \\ E-mail: andrea.galierikova@fpedas.uniza.sk
}

\author{
Matúš Materna \\ University of Ziilna \\ Air Transport Department \\ Slovakia
}

\author{
Andrej Dávid \\ University of Ziilna \\ Department of Water Transport \\ Slovakia \\ E-mail: andrej.david@fpedas.uniza.sk
}

\author{
DOI 10.17818/NM/2021/3.8 \\ UDK 341.362.1 \\ 347.799 .4 \\ Review / Pregledni rad \\ Paper accepted / Rukopis primljen: 30. 4. 2020.
}

\section{Summary}

Maritime and civil aviation security is a global problem posed by terrorism and illegal acts and therefore requires global attention and solutions that can only be provided by relevant international organizations (International Maritime Organization and International Civil Aviation Organization). Nineteen years have passed since the attacks of 11 September 2001 on the World Trade Center, but the threat of another terrorist attack is still just as possible and unacceptable. The series of attacks in the USA have started a new period of history. This period can be characterised as unsteady, unpredictable, and transforming of complex systems, including new types of dangers. The paper provides a comprehensive analysis and comparison of the most serious types of unlawful acts (terrorism and piracy) regarding legislation and jurisdiction. For the sake of comparability of legal phenomena, special attention is paid to illegal acts at sea and in the airspace above the sea.

\section{Sažetak}

Sigurnost u području pomorskog prijevoza i civilnog zrakoplovstva predstavlja globalni problem koji je nastao kao posljedica terorističkih i nezakonitih radnji, te kao takav zahtijeva globalnu pozornost i rješenja koja samo odgovarajuće međunarodne organizacije (Međunarodna pomorska organizacija i Međunarodna organizacija za civilno zrakoplovstvo) mogu pružiti. Prošlo je devetnaest godina od napada na zgrade Svjetskog trgovačkog centra 11. rujna 2001., a ipak još uvijek postoji rizik od mogućeg terorističkog napada. Niz napada u SAD-u značio je novo razdoblje u povijesti čovječanstva. To razdoblje može se opisati kao nestabilno, nepredvidljivo $i$ kao doba koje je dovelo do promjena u oblikovanju složenih sustava, uključujući i nove vrste ugroza. $U$ ovome radu dana je sveobuhvatna analiza $i$ usporedba najozbiljnijih vrsta nezakonitih radnji (terorizam i piratstvo) s obzirom na zakonodavstvo i sudsku nadležnost. Kako bi se pravni fenomeni mogli usporediti, posebna pažnja posvećena je nezakonitim radnjama na moru i u zračnom prostoru iznad mora.

\section{KEY WORDS}

maritime terrorism

maritime piracy

unlawful interference

safety

security

civil aviation

airspace

\section{INTRODUCTION / Uvod}

Terrorism is considered as the worst type of unlawful act. This social phenomenon is currently presented as the potentially greatest threat immediately after the war. It poses a threat to the security of people, property, states, the democratic establishment, and the natural development of human society. Terrorism is an instrument of forcibly promoting social interests. Although this unlawful act has many forms, its basic feature is its globality. The manifestations of terrorism are influenced by economic, political, religious, historical, social, cultural, and other conditions (Hansut \& David, 2018). Terrorism in both air and maritime transport poses a huge threat not only to people but also to world trade. The prerequisite of terrorism is the paralysing of world trade and security regardless of human lives, influenced primarily by political and religious motives. On the other hand, piracy, currently mainly in maritime transportation, means a threat of financial damage. Modern Somali pirates attack seagoing vessels with the prospect of enrichment, but, unlike terrorists, they try to avoid injuries or killings (Møller, 2009).

Both unlawful acts at sea and in civil aviation require prosecution and punishment of offenders involved. Following chapters provide a comprehensive overview of legal standards defining unlawful acts in maritime transport and civil aviation, jurisdiction and the assessment of such acts.

\section{LITERATURE OVERVIEW / Pregled literature}

Unlawful acts at sea are an urgent global problem of the present century and pose economic, cultural, religious, environmental and humanitarian risks. For this reason, more and more scientific publications and studies on operational, organizational, economic and political implications are dealing with this alarming issue to examine the impact on the current economy and security of each country. A comprehensive review of the literature has shown that maritime safety research has been studied from many perspectives, including the pirate code and hostage obligations (Zavesický, 2009), behaviour, purpose, and areas where modern pirates operate (Hansut \& David, 2018). Also, the most important base for this research represents mainly legal framework - United Nations Convention on the Law of the Sea (UNCLOS) (1982) defining the term of piracy; and also Convention for the Suppression of Unlawful Acts 


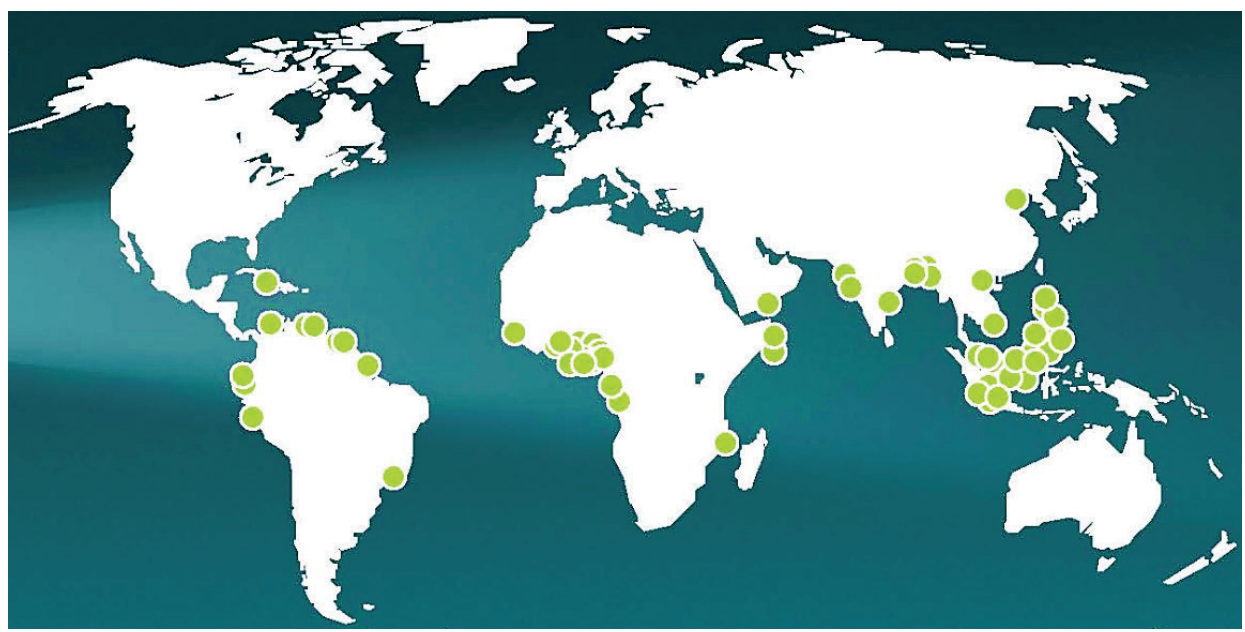

Figure 1 Sea Attack Areas in 2018

Source: ICC-IMB, 2019

Slika 1. Područja napada na moru u 2018.

Against the Safety of Maritime Navigation (SUA) (1988), defining the term of terrorism. Bahar (2007) and Allesandri (2019) comments the issue of jurisdiction on the high seas, and also provide their opinion about the terms used in UNCLOS - mainly in the way of corrections and replenishment. UNCLOS (1982) provides the information about the maritime and airspace zones for the correct performance of jurisdiction, mainly over the high seas. Cassese (2003), and Arasly (2005) describe the origin as well as the current situation in the field of aerial terrorism and civil aviation offenses. Several insights into issue of civil aviation terrorism are provided - Schmid (1997) and Krejci (1997) offer a different outlook on the terms of unlawful acts, mainly the terrorism. The most significant documents, dealing with the security of civil aviation, jurisdiction and protection of member states, that were used to process the outputs of the article, were:

- Convention for the Suppression of Unlawful Acts Against the Safety of Civil Aviation (1973),

- Convention for the Suppression of Unlawful Seizure of Aircraft [Hijacking / Hague Convention] (1970),

- Convention on Offences and Certain Other Acts Committed on Board Aircraft (1963),

- Convention Relating to the Regulation of Aerial Navigation (1919),

- Convention On the Suppression of Unlawful Acts Relating to International Civil Aviation done at Beijing (2010),

- Convention on International Civil Aviation (1947).

Novák-Sedlackova and her colleagues significantly supplement these agreements and clarify their content with the help of many publications.

\section{MARITIME TERRORISM \& PIRACY / Terorizam i piratstvo na moru}

Connections between pirates and terrorists are minimal because the objectives of these organizations differ. Pirates are driven mainly by financial motives and the vision of enrichment, while terrorists, on the other hand, are mainly driven by cultural, religious and political beliefs. Piracy, as opposed to terrorism, is therefore largely theft and enrichment, usually satisfied with stolen cargo or money, and almost always the ship and crew are released. On the other hand, terrorism usually refers to violence without distinction, in order to influence the government or international organizations for political purposes.

Areas in which both types of offenders operate most often are a common feature of both types of such lawbreakers. According to statistics ICC-IMB (2018), the most vulnerable areas are mainly the Somali coast, the Red Sea (Suez Canal), the Strait of Malaya and the Gulf of Aden. The Somali pirates are currently the most dangerous group of pirates. This type of pirates (in contrast to pirates operating in other parts of the world) is mainly interested in the kidnapping of the ship and crew. According to Zavesicky (2009), Somali pirates operate in two territories - the high seas east of the Somali coast and the territorial waters of Kenya; the second area is the Gulf of Aden. The pirates are well organized, working in small groups along the coast, applying rules ${ }^{1}$ and hierarchy between them, using satellite navigation and advanced communication technology, equipped with modern weapons thanks to the blooming arms trade in the country.

Although piracy has been a Somali problem for over 20 years, it has seen rapid growth since 2005. Since 2007, pirates have shifted their activities from the Mogadishu port area to the Gulf of Aden, and from their bases in Puntland continue to the Indian Ocean (Figure 1). In this area, hijackings are an important source of income and work for hundreds of people, including those who supply fuel supplies and equipment to pirate ships. "Thanks to" the piracy, many people prosper, so local authorities are not interested in intervening against him. With a long coastline, a dysfunctional government, a desperate and war-accustomed population, Somalia is an ideal environment for the development and functioning of piracy.

\subsection{Terminology of unlawful acts in maritime transport / Terminologija nezakonitih radnji u pomorskom prijevozu}

United Nations Convention on the Law of the Sea (UNCLOS) (1982) defines piracy as an act, depending on any of the following acts:

a) all illegal acts of detention, violence or depredation, committed for private purposes by the passengers or crewmembers of a private vessel or aircraft, and directed: i. on the high seas, against another vessel or aircraft, or against persons or property on board such vessel or aircraft; ii. against a vessel, aircraft, persons or property, outside the jurisdiction of any State;

'Pirates use their own justice system for violating the "code of good conduct", which sets out their obligations to the hostages (prohibition of robbing, killing or raping women, but also among themselves - death penalty for killing, group exclusion for injuring another pirate or death penalty for slaughter). The distribution of ransom fees for the abducted vessel is stepped up according to the degree of the cause. (Zavesicky, 2009) 


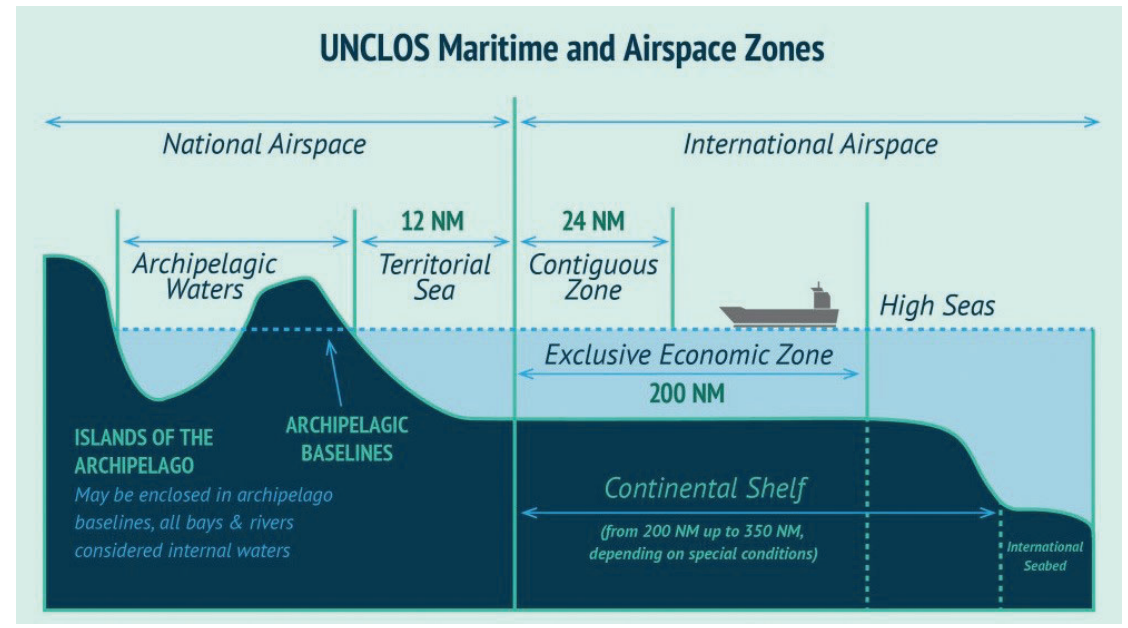

Figure 2 UNCLOS maritime and airspace zones

Slika 2. UNCLOS pomorske i zračne zone

Source: European Commission, 2015

b) any act that could be considered as a voluntary participation in the operation of a vessel or of an aircraft with knowledge of facts making it a pirate vessel or aircraft;

c) any act of provoking or of intentionally facilitating an act defined in subparagraph a) or b).

In order to classify such unlawful act as a piracy according to

UNCLOS (1982), several important requirements must be satisfied:

1. piracy must involve criminal acts of detention, violence or depredation,

2. the act must be committed for private purposes,

3. the act must be committed while using a private vessel,

4. the attack must be directed against another ship; an unlawful act, committed by a crewmember, but not against another ship, shall not be regarded as piracy. It must involve two ships.

5. the act must occur on the high seas or outside the jurisdiction of any other State. Actions committed in an area of less than 12 nautical miles are considered as armed robbery.

According to Ranstorp and Wilkinson (2005), terrorism can be defined as systematic intimidation, usually for political purposes. By means of coercion, terrorists create an atmosphere of fear, and the victims of violence must respond to their demands that lead to the attainment of terrorist objectives. Maritime terrorism has no internationally used and valid definition. The operational definition of maritime terrorism based on the Convention for the Suppression of Unlawful Acts against the Safety of Maritime Navigation (SUA) (1988) is currently being used, although this Convention does not directly concern terrorism.

Thus, according to SUA (1988), maritime terrorism represents any attempt or threat of violent control of a vessel with the aim to:

- destroy or damage the vessel or the cargo carried,

- hurt or kill a person on board the vessel,

- jeopardize the safe shipping from the territorial waters of one State to the territorial waters of another State or on the high seas.

Often, it is not possible to clearly define when piracy and terrorism are concerned ${ }^{2}$. The fundamental difference is the choice

${ }^{2}$ An example is the 2010 incident, when Somali pirates took control of the tanker Asphalt Venture. The vessel was detained in Kuluba, on the northeast coast of the Indian Ocean in Somalia. After a multi-million dollar ransom was paid, the vessel with 8 crew members was released in April 2011, while the remaining 7 crew members of the target. Pirates, who are driven by financial motives, choose a vessel carrying valuable consignments, terrorists choose vessels that can be used as a weapon (vessels carrying dangerous goods).

\subsection{Maritime zones in relation to unlawful acts / Pomorske zone s obzirom na nezakonite radnje}

The United Nations Convention on the Law of the Sea (1982) established the delimitation of maritime zones. The maritime zone has a major impact on whether a piracy will be assessed under international law (if it takes place on the high seas); under national law (if carried out on the high seas) or under the national law of the coastal State (if the attack takes place in territorial sea).

\section{High seas}

UNCLOS (1982) defines high seas as"the parts of the sea, that are not included in the exclusive economic zone, in the territorial sea or in the internal waters of a State, or in the archipelagic waters of an archipelagic State". In the area of the high seas, six fundamental freedoms apply:

a) navigation

b) overflight

c) to lay submarine pipelines and cables

d) to construct artificial islands and other installations permitted under international law

e) fishing

f) scientific research.

The above-mentioned 6 fundamental freedoms are based on the principle that the high seas should serve the common use of all states (res communis omnium) and no state may exercise sovereignty over the high seas. The flag State has jurisdiction over ships navigating in the high seas. A military ship (aircraft) can only exceptionally stop and inspect a merchant ship of another state, and only if it is suspected of being a pirate ship or a ship used for the slave trade and the drug trade (UNCLOS 1982, Art. 107).

The actions taken by military ships and aircraft against Somali pirates on the high seas are therefore in line with international law. UN Security Council resolutions have extended the power of states to act against pirates to Somali's territorial waters.

were detained by pirates ashore. In exchange for the safe return of the remaining 7 detained crew members, they demanded the release of 100 pirates detained by the Indian Navy in previous months. After many negotiations, the remaining 7 men were released in October 2014, paradoxically after paying low costs for transporting the hostages to their destination. (Maritime Security Review) 


\section{Territorial sea}

The territorial sea is defined by UNCLOS (1982) as "narrow belt of ocean, immediately seaward of the coast". Its breadth can be set by a unilateral legal act but must respect the maximum outer limit of the territorial sea ( 12 nautical miles, i.e. about $22 \mathrm{~km}$ ) measured from the baseline. Determining the exact breadth is important because the outer border of the territorial sea is the state border of the coastal state. The territorial sea, the airspace above it and its seabed are covered by the territorial sovereignty of the state. However, in the interests of freedom of navigation, this is limited, and the state must allow peaceful voyages of foreign ships (the ship does not endanger the peace, public order or security of the coastal state) from the high seas to the internal waters of the state or its port and vice versa. The exclusive power of the state is also limited in the area of civil and criminal jurisdiction. However, special rules apply to the navigation of warships through coastal waters.

\subsection{Resolution of unlawful acts at high seas / Postupanje u slučajevima nezakonitih radnji na otvorenome moru}

UNCLOS (1982) contains several rules to suppress piracy on the high seas. The general duty of all states is to cooperate in full measure to supress piracy on the high seas or in another place that is not under the jurisdiction of any state.

Particularly important is Art. 105 (identical to Article 19 of the Convention on the High Seas (1958)), according to which on the high seas or in a place not under the jurisdiction of any State, a State may confiscate a pirate ship or aircraft used by pirates ${ }^{3}$ and arrest property or persons on board of vessel. The fact that any state can capture and convict a person accused of piracy makes this crime exceptional in international law, which emphasizes sovereignty and jurisdiction over its own territory.

According to UNCLOS, Art. 105, a country party to this Convention has the right, but not the obligation, to assume jurisdiction over piracy, even though it has nothing to do with it. States that did not ratified the Convention have the same authority, but in their case, this is derived from customary international law from which this principle derives.

Sturma (2009) argues that in case of reasonable suspicion of using a vessel for piracy, warships have the right to inspect the ship. However, it is only a matter of the State's authority, as well as the right to stop such a ship, seize it and arrest persons on board. It can only be implemented by states with warships and aircraft. It is not their duty, so there is no guarantee that states with sufficient naval forces will implement these measures, especially when pirate attacks take place in remote areas off their coasts and outside their sphere of power. This weakens the effectiveness of the fight against piracy ${ }^{4}$.

The issue of criminal sanctions against pirates is not regulated by international law codified in the Convention (1982) and is left to national criminal law. However, national definitions of piracy may not only differ from international ones, but some states

${ }^{3}$ A pirate-controlled ship can preserve its nationality. Its retention or loss is determined by the law of the state that granted this jurisdiction. However, by means of violence, a pirate vessel loses the protection of the flag state and, despite the fact that the flag used indicates its true affiliation, is subject to criminal sanctions by the state which caught the pirate ship with its warship. (UNCLOS 1982, Art. 104)

${ }^{4}$ According to UNCLOS, Art. 107, seizure of a ship for the purpose of piracy may be achieve exclusively by military aircrafts or warships or by other ships and aircraft so designated. In Art. 107 expresses the possibility rather than the obligation of the state to act. On the other hand, Art. 100 imposes an responsibility on states to cooperate in suppressing piracy. By combining the two articles, we can conclude that states cannot refuse to take action against pirates. This is particularly important with regard to coastal states. may not have the issue of piracy regulated in their legal systems, and the Convention (1982) does not impose this obligation on them. Nor does the Convention (1982) seek to unify any different legislation. "Although most acts committed by pirates could be prosecuted under other provisions of criminal law, there is no guarantee that each state will be able and willing to exercise its jurisdiction in practice." as defined by UNCLOS (Sturma, 2009).

\subsection{Assessment of unlawful acts at sea (generally) / Određivanje nezakonitih radnji na moru (općenito)}

As already mentioned in Chapter 2.2, piracy, as defined by UNCLOS, does not include acts committed for political purposes in ports, inland or coastal waters; nor acts involving a single ship.

However, terrorism, although not internationally defined, usually refers to violence without distinction, in order to influence international organizations or the government for political purposes. Some counter-terrorism treaties are sufficiently comprehensive and therefore cover piracy. Such an agreement is the Convention for the Suppression of Unlawful Acts against the Safety of Maritime Navigation (SUA) and the International Convention against the Taking of Hostages (1979). The SUA Convention addresses the issue of terrorist activities on ships but is not specifically designed to combat piracy. The Convention was drafted by the International Maritime Organization (IMO) and currently has 151 parties, including the United States.

Under this convention, many acts of piracy can be considered a criminal offense. SUA commits States Parties to criminalize armed robbery at sea. Thus, an offense not falling under the definition of piracy under UNCLOS may fulfil the characteristics of an offense under SUA. The latter convention covers the crime of taking hostages, which involves holding the crew for ransom, a typical practice of pirates in Somalia.

The aim of both conventions is to require states to comply with their obligations under international treaties and to criminalize in their national law criminal offenses under international conventions $s^{5}$, The issue of sea piracy has been elaborated in more detail in other follow-up conventions. It is primarily the Convention for the Suppression of Unlawful Acts against the Safety of Maritime Navigation (1988). The Protocol for the Suppression of Unlawful Acts against the Safety of Fixed Platforms Located on the Continental Shelf (SUA PROT) (1988) was adopted to that Convention. These amendments also include older International Convention for the Protection of Submarine Telegraph Cables (1884).

\subsection{Jurisdiction and prosecution in maritime transport / Sudska nadležnost i kazneni progon u pomorskom prijevozu} According to UNCLOS (1982), states are allowed to detain a pirate vessel. However, after the arrest, the question arises of dealing with the attacker so that the subsequent steps are in line with international law.

General international law shows states to punish crimes. This obligation can be fulfilled by the state only if the condition of territoriality (the act was committed in its territory) or personality (its members) is met.

According to David, et al. (2008), if the state does not fulfil its obligation even though the conditions for the exercise of

${ }^{5}$ This commitment is reflected in the obligation of states to extradite or prosecute a suspect (aut dedere aut judicare). Although these conventions are commonly considered "counter-terrorist", "terrorism" appears only in their preambles. A terrorist motive is not a component of any crime. These conventions can be a useful tool against piracy in many cases, but even in them piracy is not classified as terrorism. 
jurisdiction are met, or further instigates, the right of every member of the international community is to punish such crimes. Somalia, for example, as a state with a dysfunctional government and institutions, in the case of pirates operating on the high seas, does not fulfil the condition of territoriality. It is possible to consider the possible competence of Somalia on the grounds of the nationality of the perpetrators. But the failing state has no means to detain or punish pirates. According to Art. 105 of the UNCLOS Convention, it therefore remains up to the international community of states which are also entitled to do so on the principle of universality the rule of universal jurisdiction ${ }^{6}$. The principle of universality is the right of every state to conduct a trial with a person accused of an international crime, regardless of the nationality of the offender or the victim and the place where the crime was committed.

International law allows any state to detain and try any pirate, regardless of whether he attacked his ship, whether the pirate is a national or otherwise affected. An attack on the high seas leads to a clash of different nationalities and thus to the possible impact of the jurisdictions of several states.

It is necessary to know the difference between piracy under national law and piracy under international law. A criminal act under national standards does not have to be defined within the international law and the principle of universal jurisdiction does not apply to it. Bahar (2007) argues that a crime in the territorial sea of a state that falls within its jurisdiction is not a violation of international law but a violation of the national standards of the coastal state, and only the state concerned has the power to take action against the perpetrator. Universal jurisdiction shall not apply ${ }^{7}$.

Applying universal jurisdiction in practice is not an easy procedure. According to it, the state should follow its national law in prosecuting and punishing a pirate. However, states often do not have the principles of international law incorporated into their criminal law, and their criminal law does not recognize the crime of piracy. Another reason is that they do not want to play the "world policeman" and they want to avoid the problems associated with the transport of suspects to their country, the associated high costs, etc.

\section{Problems with the exercise of jurisdiction}

Experts assent that the existing legal framework is sufficient to combat piracy and no major changes are needed ${ }^{8}$. However, the question arises as to why it is a problem for states to detain pirates and then punish them accordingly if international law gives them sufficient rights to do so.

Under international law, robbery or abduction at sea is considered a piracy only if it was committed on the high seas (Allesandri, 2019). Allesandri (2019) also argues that in the event of a piracy in the coastal waters of a state, it will be an armed robbery and the naval crews of foreign states cannot intervene, because only the coastal state is entitled and obliged to do so.

The exception is Somalia, which does not have a coastguard or an effective government to deal with the problem. UN

${ }^{6}$ It was originally used in cases of sea piracy, where each state was entitled to capture a person suspected of piracy, regardless of their nationality and place of crime. In the background of this departure from the principles of territoriality and personality, there was a need to fight together against forms of crime that affected all states and their common interests. Modern criminal law has extended the rule of universal jurisdiction to torture, war crimes and other crimes.

${ }^{7}$ Such a procedure is not a problem as long as the coastal State: (a) has laws recognizing the crime of piracy; (b) has an interest in enforcing compliance; c) is able to do so (which, for example, is not the case with Somalia).

${ }^{8}$ See the 'Geneva Convention on the high seas' of 1958 (articles 14 - 22) which main provisions have been paraphrased d in the UN Convention on the Law of the Sea (UNCLOS), 1982 (articles 100 - 107).
Security Council resolutions have extended the power of states to act against pirates in Somalia's coastal waters, and all activities in the country must be in cooperation with the local government (Allesandri, 2019).

Only military and related ships representing the state are authorized to strike against pirate ships. The navy is limited in its activities. It may inspect a suspicious ship, but it cannot detain the crew unless it has sufficient evidence that the crew has been involved in piracy (and the weapons on board are not sufficient evidence; most vessels sailing off the coast of Somalia have weapons on board, mostly for self-defence against pirates). The counterattack should be adequate, the use of force as a prevention is not allowed.

If it manages the pirates to be detained, questions arise about the way forward, e.g. about the time between their detention and handing over to the competent authorities, which takes often a few days. The holding of pirates on board also raises human rights issues, as the conditions of the European Convention on Human Rights to the necessary standard for detainees are not met. Another problem is that pirates are often teenagers. Human rights must be respected in anti-piracy actions.

Following detention, the question arises as to where they should be transferred for investigation and prosecution?. The multinational nature of the ship may appear to be a problem due to the different nationalities of the pirates, passengers, shipowner, crew, cargo owner, port, and ship's flag. In the case of piracy, it is not necessary to take these factors into account, because under international law, all states have the right to bring pirates before their courts.

The biggest problem is the lack of political will of states, their difficulties in prosecuting due to problems with gathering evidence and investigations and proceedings in general. The decision to prosecute can take months. During this time, suspects must be kept on board their ship or the ship that detained them, none of which are designed to hold people safe in such situations, but in adequate human conditions. Delays in the decision to prosecute or refer a case to a third party may provide an opportunity to destroy the evidence. Another problem is the detention of a suspect in one place and the prosecution in another; this entails difficulties in applying the correct rules of investigation unless it is known according to which country jurisdiction they will be proceed.

International cooperation is needed for successful prosecution and information sharing are also important. Identifying pirates is often difficult, as pirates can be anyone, from former fishermen to former members of the military who know how to fight, control a military system, GPS, and a radio station. The international element of the parties in any court proceedings must also be considered. Each of them may be a national of a different state, their presence at the trial must be ensured so that they can act as potential witnesses, and this is, of course, associated with increased costs. Another problem may be the language of the piracy suspects and the need for an interpreter.

\section{UNLAWFUL ACTS IN CIVIL AVIATION / Nezakonite radnje u civilnom zrakoplovstvu}

Terrorism is not a phenomenon of modern age. Obviously, terrorism, an act of socio-political ends is seen during the

${ }^{9}$ Africa Program and International Law Conference Report: Piracy and Legal Issues: Reconciling Public and Private Interests. [Online]. Available from: <http://www. chathamhouse.org.uk/files/15221_011009piracy_law.pdf>. 
whole the history of humankind. However, in the $21^{\text {st }}$ century, terrorism has developed into a crucial geopolitical element, able to cause a systematic global crisis. According to Cassese (2003), the beginning of modern aviation terrorism is $22^{\text {nd }}$ of July 1968 , when 3 attackers from the Popular Front for the Liberation of Palestine (PFLP) hijacked a passenger airliner of the El Al Israeli airline on a flight from Rome to Tel Aviv, and demanded to swap hostages for their comrades-in-arms, who were imprisoned in Israel ${ }^{10}$. An explosive growth was marked in 1970s, most of them followed with a typical standard - armed attack of an airliner, hijacking to a safe airport, taking hostages with the regard on the political purpose. In 1980s, tendency toward the further spread of terrorism in aviation as a political pressure tool came to an end because of several factors, such as fast improvement of technical means of airport security, creation of special antiterrorism teams and also implementation of measures by a several states against terrorist leaders. Nevertheless, the aviation terrorism did not disappear, terrorists only changed a technique. In considering the mentioned examples, it is one to million chance that the biggest terrorists attack the world ever seen (the attacks from the $11^{\text {th }}$ of September) were executed by hijacking civil airliners. Exceptionally, the airplanes were steered by suicide pilots - for the first time airliners were used as weapons (Arasly, 2005). The terrorist attacks of 11 September 2001 have started a new period in modern history. The period represents instability, unpredictability. Also, redesign of complex systems, involving both new and known types of challenges and hazards. The issue of emergence of terrorism is nowadays a truly global threat.

So, in general, there are several insights about the civil aviation terrorism - according to Schmid (1997), terrorism can be considered the deliberate use of violence (or threats), usually directed against non-participants, in order to create fear through which political, religious, or ideological goals are achieved. Terrorism also includes crimes, which are essentially symbolic and are a way to achieve goals for others than those for which the crime is aimed. Krejci (1997) argues that all crimes committed by individuals and groups that can be used against the state, its institutions, the population, motivated by separatist efforts should be considered and punished as terrorist acts. Its aim is in exposing the public authorities, certain individuals, social groups, or public opinions in general to spread of an atmosphere of fear.

\subsection{Airspace above the Territorial Sea in relation to acts of unlawful interference to civil aviation / Zračni prostor iznad teritorijalnog mora u odnosu na radnje nezakonitog uplitanja u civilno zrakoplovstvo}

An aircraft in the airspace can become not only an instrument of a terrorist attack, but also a victim of an armed act by a subject of international law, i.e. the state. Airspace is part of the state territory. It is fully and exclusively subject to the sovereign authority of the territorial state. Convention on International Civil Aviation (Chicago Convention) in Art. 1 provides that every State has exclusive and complete sovereignty over the airspace above its territory.

Given that the sea occupies more than $70 \%$ of the earth's surface, the regulation of airspace over individual sea areas and zones is very important for international aviation. International

${ }^{10}$ This operation was the first case of hijacking not out of criminal motivation of for personal reasons, but with the specific purpose of politically pressuring the other side, using the incident as a propaganda message with a political regard. air law documents, mostly the Chicago Convention and its annexes, but also other international agreements, are commonly applied to airspace over individual sea areas, such as:

Regulation (EC) No 551/2004 of the European Parliament and of the Council of 10 March 2004 on the organisation and use of the airspace in the Single European Sky,

ICAO provisions, policy and guidance material on the delegation of airspace over the high seas,

The Law of the Air and the Draft Articles Concerning the Law of the Sea Adopted by the International Law Commission at Its Eighth Session Extract from the Official Records of the United Nations Conference on the Law of the Sea, Volume I

\section{Flight over territorial seas}

The provisions of the Convention relating to coastal waters clarify the principles of general international law. The sovereignty of a coastal State spreads outside of its land territory and national waters to coastal waters. This sovereignty is also applied to the airspace above coastal waters. Article 3 of the Convention set its exact width at 12 nautical miles $(22.2 \mathrm{~km})$.

The problem may occur with the flight over the archipelago waters, because even in this case, the aircraft pass through the territory of a sovereign state. The use of overflight rights is essential for certain types of states, as important areas of the world's oceans are the sovereign territories of states such as Indonesia, the Philippines, Japan, Malaysia etc.. Within the respect to the principle of sovereign equality, the archipelagic state can also set its default border lines (on land and on water) to determine its borders in inland waters, territorial waters, an exclusive economic zone, or a land shallow.

\section{Flying over the high seas}

UNCLOS (1982) defines the high seas as the area of the sea, not included in the exclusive economic zone, in the coastal, internal or archipelagic waters of a State. The basic principle of the legal regime of airspace over the high seas is the principle of freedom of overflight according to which aircraft of all states have guaranteed the right to fly freely in this area. Airspace over the high seas is excluded from the competence of any state. The sovereignty of one or more states cannot be extended to it. This airspace is not part of any state territory. Therefore, any negotiations by States aimed at extending their competence in the airspace over the high seas must be classified as unlawful. No state has the right to prevent another state from exercising its free flight over the high seas. Any aircraft located in the airspace over the high seas shall be inviolable and completely independent of the authority of another State other than that in which it is registered. Aircrafts of other states have no right to demand a change of course and route on such an aircraft, or otherwise they violate the freedom of flights over the high seas.

In relation to the airspace over the high seas, all States have the following rights (UNCLOS, 1982, Art.87):

operate flights of civil and military aircraft,

exercise authority over their aircraft and its crew,

use air navigation aids to control and manage flights in order to ensure their safety,

observe the situation at sea from aircraft in the interest of military, scientific research, industrial or commercial ships, pursue a foreign vessel on the high seas for violating the laws of the coastal state,

use aircraft to combat piracy and the slave trade. 
Free flight over the high seas means for states not only the recognition of their certain rights, but also the assumption of certain obligations. When exercising the freedom to fly in the airspace over the high seas, States shall:

follow the rules of the flight recommended by ICAO,

prevent pollution of the airspace over the high seas in all

activities involving the use of radioactive substances or other harmful substances,

prevent incidents in the airspace over the high seas,

assist ships and aircraft in distress,

not abuse the airspace over the high seas for nuclear experiments,

- refrain from force or threat of force.

States are obliged to respect these rules and to ensure that their aircrafts comply with their operator (Convention on International Civil Aviation, 1944).

\subsection{Motivation for unlawful acts in civil aviation / Motivacija za nezakonite radnje u civilnom zrakoplovstvu} Hijackers of civil transport aircraft tend to be motivated for several reasons. Unlike the traditional notion of piracy on the high seas, where the main motive for its commission was private gain, air piracy poses a threat of international significance. A civil aircraft can be used as a tool to raise funds, as can the hijacking of a transport aircraft for other purposes. The hijacking of a transport aircraft is quite often used to put pressure on the government. It is also one of the options for dissidents or criminals to leave the country. The motives for hijacking civil aircraft can therefore be divided into politically or ideologically oriented ones, as well as those used exclusively for private purposes.

Joyner (1974) defined several categories of civil aircraft hijackers. Their motives are often of a purely private nature. The actors are most often mentally disturbed people, with the so-called Hijacker syndrome, which in this way tries to attract media attention, which can border on political reasons. Hijackers can also be mentally unstable individuals who have not managed personal problems such as dismissal - then they are mentally unstable, and their actions are therefore without obvious political connection. Another type of kidnappers are persons who act to blackmail and gain profit, or persons who are prosecuted and try to escape serving a sentence.

The political subtext of the hijacking is typical form refugees from political persecution. It is the most common way to travel freely from a country with an undemocratic regime (countries of the former Soviet Union, Cuba, South Vietnam or Czechoslovakia). Another category of politically motivated kidnappings has become a trip to a politically isolated country. Most of the cases concerned Fidel Castro's supporters who, due to the lack of air infrastructure, were unable to travel to Cuba from countries such as Colombia, Venezuela, and the United States. The last group is represented by the motives of antagonistic political groups, for reasons of protest or propaganda. Joyner (1974) also includes terrorist activities against civil aviation and air sabotage.

\subsection{Legislation on preventing of unlawful acts acts / Zakonodavstvo o sprječavanju nezakonitih radnji}

In the later years of the 20th century, there was a need to create legislation for acts of illegal interference in civil aviation. States first concluded multilateral agreements or conventions. However, as Novak-Sedlackova \& Kandera (2015) claims, the first international legal document regulating this issue was the Convention on the
High Seas (UNCLOS) of 1958, which defines in Art. 15 the term piracy as an unlawful act of detention, violence or any act of robbery committed for private purposes by the passengers or crewmembers of a private vessel or private aircraft aimed at:

- on the high seas against another vessel, aircraft or persons or property,

against a vessel, aircraft, person, or property in the area not under the jurisdiction of any state.

The Convention on Offenses and Certain Other Acts Committed on Board Aircraft (1963), as the first defined one of the forms of unlawful conduct on board an aircraft (unlawful seizure of an aircraft). According to Art. 11, if any person on board an aircraft in flight, uses unlawful violence or threat of violence during to interfere with the control of the aircraft, seize the aircraft or otherwise unlawfully exercise control over the aircraft, or threatens to commit such an act, States Parties should take the necessary countermeasures to ensure the aircraft has been returned to the authorized control of the aircraft, or to retain its control (Novak \& Novák Sedláčková, 2015). However, the Convention on Offences and Certain Other Acts Committed on Board Aircraft (1963), remained only as an initial measure, it opened the problems, but did not solve them. ${ }^{11}$

The Convention the Suppression of Unlawful Seizure of Aircraft (1970) in Art. 1 defines that any person who unlawfully uses force or a threat of force to seize an aircraft during a flight on board an aircraft is liable for the commission of an intentional criminal offense against civil aviation. ${ }^{12}$

This convention was the first to show the parties to prosecute offenders and extradite them to the country of registration of the aircraft or other interested country. The Convention further obliges the signatory parties to sue and extradite the kidnappers, and to surrender the perpetrators for the execution of the sentence if it is not extradited to the State of Registry or to another interested State.

The Convention for the Suppression of Unlawful Acts against the Safety of Civil Aviation ${ }^{13}$ has defined the concept of an unlawful threat to the security of civil aviation. Such an act is considered a violent crime committed intentionally and illegally by a person on board an aircraft during a flight with the intention of endangering the safety of the aircraft. ${ }^{14}$ According to Novák \& Novák Sedláčková (2014) and Novák Sedláčková \& Švecová (2018a) was in addition to the unlawful seizure of aircraft also necessary to define equally dangerous terrorist actions, such as placing bombs on aircraft and unlawful acts directed against civil airports and their staff, because airports were a key element in the aviation and they play a serious role for economic development on local and regional levels. The importance of the security of the airport is according to Novák Sedálčková \& Švecová (2018b) special position of the airports, when mutual connection "airport - railway- highway" represents a perfect place for establishment an industrial zone with a many

\footnotetext{
${ }^{11}$ The Convention on Offences and Certain Other Acts Committed on Board Aircraft (1963) does not qualify the procedure defined in Art. 11 as a criminal offense. It is limited to the obligation of the Contracting States to take countermeasures to maintain or rehabilitate the control of the aircraft by the pilot-in-command. ${ }^{12}$ Although the Convention for the Suppression of Unlawful Seizure of Aircraft (Hijacking / Hague Convention) defines an illegal act against civil aviation, (aircraft, crew and passengers) is similar to the Convention on Offences and Certain Other Acts Committed on Board Aircraft, it considers such conduct to be not only illegal but also criminal. ${ }^{13}$ The Convention supplements the Protocol for the Suppression of Violent Acts of Violence at Airports Serving International Civil Aviation.

${ }^{14}$ This definition includes causing damage to aircraft in- flight, to aircraft in service and to equipment providing services during air traffic control; organizing the location and the actual placement of equipment and objects on board the aircraft, which may cause damage to the aircraft or endanger flight safety; it also applies to a person who disseminates alarm messages and false information that endangers flight safety.
} 
activities in the transportation, industry and tourism sector, which can be a very big attraction for potential terrorists.

According to $13^{\text {th }}$ Article of Convention for the Suppression of Unlawful Acts Against the Safety of Civil Aviation (shortly Montreal Convention), the Signatory Parties undertake to provide the ICAO Council with information as soon as possible on:

the conditions of the crime,

the actions took to return control of the aircraft to an authorized person,

assistance to passengers, crew and owners of aircraft or cargo, the measures taken against the (including the alleged) offender and in particular the results of any extradition proceedings or other legal decisions.

The information provided is used by the ICAO Council to develop relevant standards and recommendations. So, the Contracting States shall undertake all practicable measures to prevent the offences or attacks as mentioned in Article 1 of Convention for the Suppression of Unlawful Acts Against the Safety of Civil Aviation. According to the Convention on the Suppression of Unlawful Acts Relating to International Civil Aviation (shortly, the Beijing Convention). Parties that ratify the Convention agree to prosecute particular terrorist acts against the security of civil aviation. This convention entered into force on 1 July 2018 following Turkey's accession to it. States also agree to sue using hazardous materials to attack aircraft or other objects on the ground and using civil aircraft as a weapon. The illegal transport of nuclear, chemical or biological weapons is also criminalised. The creation of a new aviation security convention that would focus on the threats in the sector of civil aviation was partly prompted by the September 11 attacks.

\subsection{Jurisdiction and prosecution in civil aviation / Sudska nadležnost i kazneni progon u civilnom zrakoplovstvu}

According to Novak Sedlackova \& Kandera (2015), if the aircraft is located on the ground or in the airspace of the state of its registration, this state exercises full jurisdiction over the aircraft. States have the right to establish regulations based on which they will assess illegal crimes committed on their territory and can determine the manner in which offenders are punished. The Convention on Offences and Certain Other Acts Committed on Board Aircraft, Convention for the Suppression of Unlawful Seizure of Aircraft (Hijacking / Hague Convention) and Convention for the Suppression of Unlawful Acts Against the Safety of Civil Aviation (1973) apply only in cases where the aircraft is flying over the territory of a State other than the State of registry of the aircraft. ${ }^{15}$

For the purpose of determining the commission of an offense on board an aircraft, an interpretation of the term "aircraft in flight" is required. The Convention on Offences and Certain Other Acts Committed on Board Aircraft (1963) defines this term as the time from the moment when engine power is used to take off until the engine stops on landing.

\footnotetext{
${ }^{15}$ Under International Aviation Law, each aircraft has to be registered in a certain state. Art. 77 of the Convention on International Civil Aviation (1944) provides that the ICAO Council shall determine the procedure in which a provision of the Convention is to be applied in so far as it concerns the nationality of aircraft operated between national operating agencies. All three of these conventions address the issue of registration of aircraft of the joint aviation organizations. States which found joint air transport organisations are already subject to joint or international registration shall designate among themselves, in an appropriate manner, for each aircraft a jurisdiction and a State of registry for the purpose of the Convention, thus ensuring the effectiveness of fight against crime, punishment and extradition of the offender, but also the provision of mutual legal assistance between the parties.
}

However, the Convention for the Suppression of Unlawful Seizure of Aircraft (Hijacking / Hague Convention) and Convention for the Suppression of Unlawful Acts Against the Safety of Civil Aviation define this term as the time interval from the closing of all external doors of an aircraft after the boarding of passengers until the moment when any of these doors are open for unloading and disembarkation. In the case of an emergency landing, the flight last until the competent parties assume responsibility for the aircraft and for the persons and property on board. ${ }^{16}$

If the pilot-in-command is convinced that a person has committed or intends to commit a criminal offense, he or she may take measures against that person, including any restrictions necessary:

to protect the security of the aircraft, persons or property onboard,

to sustain order and discipline onboard,

to be able to transfer such a person to the competent parties or to remove him / her.

It is important to apply the individual conventions - and therefore whether the competent authorities can be held responsible for the aircraft before and after the flight. The Convention for the Suppression of Unlawful Acts Against the Safety of Civil Aviation (1973) is also applicable during the period in which the aircraft is in service. This term is an aircraft from the pre-flight preparation start performed by ground personnel or crewmembers for a certain flight up to 24 hours after landing. ${ }^{17}$

\subsection{Application of international conventions regulating the issue of unlawful acts in civil aviation / Primjena međunarodnih konvencija koje reguliraju problem nezakonitih radnji u civilnom zrakoplovstvu}

During the preparation of the Convention on Offences and Certain Other Acts Committed on Board Aircraft (1963), Western states assumed that political motivation was the main reason for the illegal seizure of aircraft. This reasoning proved to be incorrect, as shown by the number of hijackings carried out by offenders of general crimes who sought to avoid prosecution in this way the Convention on Offences and Certain Other Acts Committed on Board Aircraft (1963) did not regulate the criminality of these crimes or the obligation to extradite offenders ${ }^{18}$. Due to the insufficiently effective provisions for battling the illegal hijacking of aircraft in the Convention on Offences and Certain Other Acts Committed on Board Aircraft (1963) this issue was addressed by the Convention for the Suppression of Unlawful Seizure of Aircraft (Hijacking / Hague Convention) and Convention for the Suppression of Unlawful Acts Against the Safety of Civil Aviation. The issue of resolving infringements in civil aviation was resolved by the ICAO Legal Committee in 1970, in accordance with the London Convention, the offense being committed by persons who illegally:

intentionally commit an armed attack against a person while flight,

intentionally destroy or seriously damage the aircraft in service, intentionally damage the aircraft in service, where in-flight

${ }^{16}$ Definitions of an in-flight aircraft are also included in the Convention on Offences and Certain Other Acts Committed on Board Aircraft, but only for the purpose of defining a period of time for the pilot-in-command's special authorization against offender of illegal acts on board an aircraft or acts endangering the safety.

${ }^{17}$ The need to introduce this concept arose from the commission of diversionary acts against aircraft during their stay at airports or other places on the ground. All three conventions apply only to civil aircraft.

${ }^{18} \mathrm{An}$ act based on international law and international treaties consisting in the transfer of a person accused or convicted by the State in whose territory heor she is located to the State requesting extradition. 
safety is compromised,

- deliberately destroy or damage air navigation equipment in order to endanger the safety of the aircraft during flight, intentionally interfere with the operation of the air service in order to endanger the safety of the aircraft in-flight,

intentionally carry on board aircraft cargo, mail or other equipment or substances that could damage or destroy the aircraft in service and endanger in-flight safety,

are accomplices of a person who attempts to commit any of the above-mentioned acts,

- participate in a conspiracy to commit any of the above acts. According to McWhinney (1973), three main categories of offenses were identified:

1. intentional acts,

2. acts inherently dangerous behaviour (e.g. placing a bomb on board an aircraft)

3. ambiguous acts may not always be intentional (e.g. transport of radio equipment on board an aircraft). These acts may or may not be performed with the intention of endangering the safety of air traffic.

According to Novak-Sedlackova \& Kandera (2015), it is necessary to introduce the concept of aircraft in operation, especially in situations of committing diverse acts against aircraft during their stay at airports or other places on the ground. The Convention for the Suppression of Unlawful Acts Against the Safety of Civil Aviation (1973) applies at the time when the aircraft is in operation. An aircraft in service is an aircraft from the start of preflight preparation performed by ground staff or crewmembers for a certain flight up to 24 hours after any landing. The period of an aircraft in service includes the entire time the aircraft is in flight.

\subsection{Possible improvements of legal framework to increasing security / Moguća poboljšanja pravnoga okvira za poboljšanje osiguranja}

Because the issue of piracy in maritime transport is sufficiently covered by the UNCLOS framework (1982), it is suggested that experts address the issue of maritime terrorism, taking into account the necessary definition of what terrorism is and what the difference between piracy and terrorism is.

However, this issue is sufficiently clarified by the Convention for the Suppression of Unlawful Acts Against the Safety of Maritime Navigation (SUA) (1988), which is currently in use, although a legal definition of terrorism at sea is still not established.

In the sterms of civil aviation, two important actions have to be taken for improving security - the first one - the proces of analysis and reporting of occurrences in civil aviation was missing. This problem was solved in February 2021 when the EU Commission published the Staff Working Document on the evaluation of its Occurrence Reporting Regulation.

An occurrence in civil aviation is a safety-related act which can endanger an aircraft and the persons onboard. The Regulation aims to improve safety information related to such occurrences reported, collected, analysed, stored, protected and exchanged. The most significant importance is given to frontline aviation professionals report occurrences that represent a significant risk to aviation safety.

To ensure reporting of such incidents, the Regulation also provides rules on confidentiality, granting protection to those reporting events, under particular circumstances, and on the certain use of information.
The evaluation reveals that the Regulation has also contributed to the overall increasing of aviation safety in the EU. Especially, it has improved reports of safety-related incidents, and increased the quality of the safety data extracted from the incident reports (European Commission, 2021)

Another significant issue that has to be considered for improving civil aviation security is creation of "megablocs" of airspace to replicate the airspace of continents. Within ICAO, which this megablock proposal supports, it seeks to ensure that air traffic control services are provided from a single location, regardless of national borders. From a technical point of view, today's modern radar and navigation technologies have a more or less global capability, but on the other hand, the basic postulate of international civil aviation law is Article 1 of the Convention on International Civil Aviation, which has been mentioned many times. However, the provisions on sovereignty will certainly not be a fundamental obstacle to creating the required operational arrangements, the problem will be finding political will and reaching agreement where there are no historical preconditions and conditions (Arab countries vs. Israel, India vs. Pakistan, etc.)

\section{CONCLUSION / Zaključak}

Unlawful acts committed at sea and in aviation are still existing phenomena that can also be resolved through international treaties and the general principles of international law. The UN Convention on the Law of the Sea (1982), which codifies customary rules in this area, is currently responding to the occurrence of unlawful acts at sea. Piracy is defined by the UNCLOS (1982) as any violent act or detention, that is illegal, and is committed for private purposes by the crewmembers or the passengers of a private vessel or aircraft directed on the high seas or in an area not under the jurisdiction of any State, against another vessels or aircraft, property or persons. In the case of proving the commission of the act of piracy, it is possible to arrest the crew, confiscate cargo and, in the event of resistance or an attempt to escape, sink the ship.

Currently, protection against piracy is a very topical issue. Piracy currently exists mainly in the Strait of Malaysia, the Caribbean Sea, the Indian Ocean (especially in the areas adjacent to the coast of West Africa, especially near Somalia). The coordination of states' activities in the field of protection against piracy is carried out by the International Maritime Organization (IMO).

The issue of unlawful acts of interference in civil aviation is regulated by various international conventions. The most important are:

Convention on Offences and Certain Other Acts Committed on Board Aircraft (1963)

- Convention for the Suppression of Unlawful Seizure of Aircraft (Hijacking / Hague Convention) (1971)

Convention for the Suppression of Unlawful Acts Against the Safety of Civil Aviation (1973)

- Convention On the Suppression of Unlawful Acts Relating to International Civil Aviation (2010).

These and other legal rules governing protection against acts of unlawful interference are enshrined in national law. Following 9/11, when the aircraft became a weapon in the hands of terrorists, the need arose to strengthen the security of civil aviation, in particular to protect lives, restore public confidence in air transport and support its economy. The strategic document is 
the ICAO Civil Aviation Security Action Plan, the main programme of which was to assess security in all ICAO Member States, an audit plan to address civil aviation security shortcomings and a follow-up study identifying priority categories of acts of unlawful interference that involve new threats. These occur in the form of aircraft misuse as weapons, air-to-ground suicide attacks, cyber or electronic attacks, chemical attacks, and the abuse of nuclear or biological materials. Convention on the Suppression of Unlawful Acts Relating to International Civil Aviation entered into force on $1^{\text {st }}$ July 2018. This new international convention aims to upgrade and reinforce the legislative for aviation security, including through the criminalization of different of terrorist acts. By criminalizing the acts representing new and threats against civil aviation, including particular preparatory acts, this tool will strengthen the capacity of States and creates moves to prosecute and punish the attackers, committing such acts (ICAO, 2018). The extensive issue of assessing crimes at sea and in the air, despite the large number of similarities, such as UNCLOS and the resulting distances at sea and in the air, has as many differences as possible. The offenders of unlawful acts focus mainly on civil aircraft. It is impossible to get on a cargo plane, so terrorists use airports. In maritime transport, terrorists and pirates do not choose the type of ship - they do not prefer a passenger vessel to a cargo vessel. The best target for the sea pirates is vessel that transports as many valuable shipments as possible, resp. about a vessel carrying tourists, because they have huge amounts of money and assume that they own electronics (Jurkovič et al., 2017). They also choose container vessels and vessels with state-ofthe-art technology on board. Cruise vessels or yachts (with lower sides) are also chosen to capture as many hostages as possible to obtain the highest possible ransom. Maritime terrorists, with the political reasons, used to choose vessels carrying large quantities of cargo in order to jeopardize world maritime trade as much as possible. Despite the choice of cargo vessels in terrorist attacks at sea, human lives are being lost, which sea pirates are trying to avoid. Although the term air piracy does not have the same meaning as sea piracy (and the term is considered an archaism in aviation) attacks in aviation and at sea have a common denominator - the fear of passengers and crew, because regardless of the motive they attack human life, which represents the highest price.

\section{REFERENCES / Literatura}

[1] Alessandri, E.: Addressing the resurgence of sea piracy: Aproaches and possible responses, International Institute of Humanitarian Law, Conference report, 2009, 16pp.

[2] Arasly, J. (2005). Terrorism and Civil Aviation Security: Problems and Trends. Connections, 4(1), 75-90. Retrieved March 24, 2021, from http://www. jstor.org/stable/26323156, https://doi.org/10.11610/Connections.04.1.05

[3] Bahar, M.: Attaining Optimal Deterrence at Sea: A Legal and Strategic Theory for Naval Anti-Piracy Operations, Vanderbilt Journal of Transnational Law, 2007, Vol. 40/1, 26 pp.

[4] Cassese, A.: International Criminal Law, 2003, Vol 2, New York: Oxford university press, $284 \mathrm{pp}$

[5] Dávid, A., Hanšút, L.: Možnosti prepravy nákladu medzi Áziou a Európou cez severnú morskú cestu, Svet dopravy, 1/2019, ISSN 1338 - 9629, pp. 25-33

[6] David, V., et al.: Mezinárodní právo veřejné s kazuistikou, Prague, 2008, pp. 134-138

[7] Convention for the Suppression of Unlawful Acts Against the Safety of Civil Aviation. International conference on air law, Montreal, 8-23 september 1971. Date of entry into force: 26 January 1973
[8] Convention for the Suppression of Unlawful Seizure of Aircraft [Hijacking / Hague Convention], 860 U.N.T.S. 105, entered into force Oct. 14, 1971. Hague. 1970

[9] Convention on Offences and Certain Other Acts Committed on Board Aircraft. Signed at Tokyo on 14 September 1963 (Tokyo Convention)

[10] Convention Relating to the Regulation of Aerial Navigation (Paris Convention), signed in Paris on October 13, 1919.1919, Paris

[11] European Commission. 2021. Aviation safety: Evaluation confirms continued relevance of EU rules on follow-up procedures following safety-related events in civil aviation. Available at: https://ec.europa.eu/transport/modes/air/ news/2021-02-18-aviation-safety-evaluation_en

[12] Hansut, L, David, A.: The piracy in maritime transport and its impact on the global world market, 18th International Scientific Conference Globalization And Its Socio-Economic Consequences, University Of Zilina, 10th - 11th October 2018, 9 Pp.

[13] ICAO, 2010. Convention On The Suppression of Unlawful Acts Relating to International Civil Aviation done at Beijing On 10 September 2010

[14] ICAO, 1944. Convention on International Civil Aviation (Chicago Convention). Done at: Chicago. Date enacted: 1944-12-07 In force: 1947-04-04

[15] Joyner N.D.: Aerial Hjacking As An International Crime, New York: Oceana Publications, Inc., 1974, Pp. 203-208

[16] Jurkovic, M., Kalina, T., Turcan, R., Gardlo, B. Proposal of an enhanced safety system on board of the inland vessel. In: MATEC web of conferences. LOGI 2017 - 18th international scientific conference: České Budějovice, Czech Republic, October 19, 2017. - ISSN 2261-236X. - Vol. 134, art. no. 00022. 2017, online, 7 pp. https://doi.org/10.1051/matecconf/201713400022

[17] Loubert, J.: The extent of maritime terrorism and piracy: a comparative analysis Scientia Militaria, South African Journal of Military Studies, 2013, Vo 41/1 pp.111-137, doi: 10.5787/41-1-1055 https://doi.org/10.5787/41-1-1055

[18] Krejci, O.: Mezinárodní politika, Praha: Victoria Publishing, 1997, 274 pp.

[19] Maritime Cyprus - International Maritime News Forum (2019), ICC - IMB Annual Report 2018: World - Wide incidents of piracy and armed robbery against ships. Available at: https://maritimecyprus.com/2019/01/17/icc-imbannual-report-2018-world-wide-incidents-of-piracy-and-armed-robberyagainst-ships/

[20] McWhinney, E.:. Aeriel piracy and international law. Oceana Publications, Inc. Dobbs Ferry, N. Y. 10522. 197337 pp.

[21] Møller, B.: Piracy, maritime terrorism and naval strategy. DIIS Report. 2009:2. Copenhagen. 36pp. Available at: https://www.peacepalacelibrary.nl/ebooks/ files/37556408X.pdf

[22] Naval Justice School (U.S.): Naval Law Review. United States. Department of the Navy, 2010 Ohio State Library - Moritz Law Library.)

[23] Novak Sedlackova, A., Kandera, B.: Medzinárodnoprávna úprava ochrany civilného letectva pred činmi protiprávneho zasahovania, Dolis, s.r.o., 2015, 133 pp. ISBN 978-80-8181-028-2

[24] Novak, A., Novák Sedláčková, A.: International civil aviation regulations. - 1. vyd. - Bratislava : DOLIS, 2015. - 150 s., [AH 6,95] : obr., tab. - ISBN 978-808181-011-4.

[25] Novák-Sedláčková, A., Švecová, D.: The regional airports position within the slovak republic: The case study of pieštany airport and the proposal of measures for its revitalization. Paper presented at the Transportation Research Procedia 35, 2018 (a). pages 209-219. doi:10.1016/j.trpro.2018.12.027 https:// doi.org/10.1016/j.trpro.2018.12.027

[26] Novák-Sedláčková, A., Švecová, D.: The Regional Airports' Problems in the Slovak Republic: The Case Study of Zilina Airport. MATEC Web of Conferences, 2018 (b). 236, $02001 \mathrm{https} / / /$ doi.org/10.1051/matecconf/201823602001

[27] Qu, X., Menq, Q.: The Economic Importance of the Straits of Malacca and Singapore: An Extreme Scenario Analysis, Department of Civil and Enviromental Engineering National University of Singapore, 2012, Singapore

[28] Ranstorp, M., Wilkinson, P. 2005. Terrorism and political violence". Terrorism and Political Violence, Ročník 17. s. 2-4 https://doi. org/10.1080/09546550590520500

[29] Scheu, H. Ch. 2010. Úvod do mezinárodního práva veřejného. Praha: Auditorium, s. 74

[30] Schmid, A. P. 1997. Problémy s definovaním terorizmu. Encyklopédia Svetový terorizmus od staroveku až po útok na USA. Praha: Svojtka \& Co., pp. 10-20. ISBN 978-80-7237-340-4

[31] Sturma, P.: Černá vlajka pirátů znovu nahání strach? Opatření proti pirátství a ozbrojenému lupičství na moři na začátku 21. století, Trestněprávní revue, 2009, Vol 8/7, pp. 193-197

[32] Vlcek, T.: Bezpečnostní hrozby a rizika tankerové přepravy ropy, 2010

[33] Watkinks, E.: Facing The Terrorist Threat In The Malacca Strait, Terrorism Monitor, 2004, Vol. 9/2

[34] Zavesicky, J.: Moderní piráti v Somálsku, Mezinárodní politika, Vol. 33/1, 2009, pp. 36, ISSN 0543-7962 